\title{
ニューラルネットワークによる ロボットの作業対象物の運動拘束認識
}

\author{
関啓 明*1 佐々木 健*2 高 野 政 晴*3

\section{Detection of Kinematic Constraint from Search Motion of a Robot Using Neural Network}

\author{
Hiroaki Seki ${ }^{* 1}$, Ken Sasaki*2 and Masaharu Takano*3
}

\begin{abstract}
In this paper, a method for detecting kinematic constraints in a plane when the shapes of the grasped object and the environment are not given is presented. It is one of the important function for intelligent tasks of home, maintenance, assembly and disassembly robots. This method utilizes the displacement and force information obtained by "active search motion" of a robot. In reality, this information includes some uncertainties such as friction, slack and elasticity. A new neural network configuration for this detection is proposed. It consists of two multilayer networks (primary and secondary network). The primary network learns the movable space (constraint) obtained by the search motion. By the generated link weights which reflect the movable space, the secondary network determines the type and the orientation of the constraint. Simulation and experimental results are presented and analyzed.
\end{abstract}

Key Words: Constraint, Search Motion, Movable Space, Neural Network, Link Weights

\section{1.はじめに}

把持した作業対象物の運動拘束を認識することは知能ロボッ トのセンシングの重要な問題の一つである．環境や対象物の形 状やモデルが与えられたり，作業が特定されている場合に接触・ 拘束状態を検出したり, 可動方向等を計算する研究は数多い。 対象物を剛体で多面体とし, 摩擦力を考虑しない場合は, 一般 的な解析や検出方法も提案されている 1$]$ [4]. また, 棒を穴 に㨂入する作業については様々な幾何学や力学の解析が行われ ており，各段階の接触状態を遷移させることによって棒の挿入 を実現している [5]〜 [7]. モデルとの誤差に適応するために外 界センサの情報と運動制御を直接結び付ける手法もある [8] [9].

本研究では，工場のように作業環境がロボット用に整備され， 対象物がほとんど既知である場合ではなく，屋外や家庭等での 作業のように未知情報が多い状況を想定し, 幾何学的情報が与 えられていない未知環境でロボットが把持した対象物の運動拘 束を検出することを目的とする. 対象物や環境の形状など幾何 学的情報があらかじめ与えられていない状態から拘束を検出す る点が他の研究 $[1] \sim[9]$ と異なる. 未知の拘束の検出が必要な 作業として次のような例が挙げられる（Fig. 1).

\footnotetext{
原稿受付 1996 年 6 月 18 日

*1 金沢大学工学部

*2 東京大学工学部

$* 3$ 関西大学工学部

${ }^{* 1}$ Faculty of Engineering, Kanazawa University

${ }^{* 2}$ Faculty of Engineering, University of Tokyo

${ }^{* 3}$ Faculty of Engineering, Kansai University
}

\section{・ホームロボットが行う家庭内の作業}

人間と設備や道具を共用するため, ロボットが通過するド アの開く方向（引き戸か? 回転か? 等) やノブの回し方 の検出, 戸棚の戸や引き出しの開閉, 水道やガスの栓の開 閉，物の収納・箱詰め・取り出し作業などがある.

- 保守・点検作業, 組立作業 プラントの保守・点検作業の一つに可動部や固定部の点検 がある，異常時には拘束状態が通常と異なる，組立，建築 等においても各作業段階での拘束状態の確認が必要である.

- 分解作業

資源再利用を目的に廃棄された多種多様な製品等をロボッ 卜が分解するとき，拘束状態の検出・識別が必要となる.

・仮想現実における拘束感提示システムへの利用 仮想現実感の一つに拘束感の提示がある．現実の拘束状態 (反力や変位) を直接そのようなシステムに取り込んでリ
Movable direction

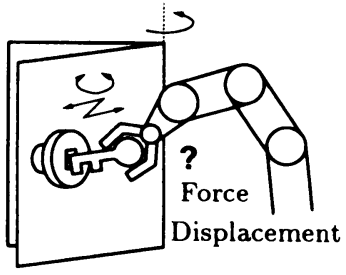

Open/Close Door

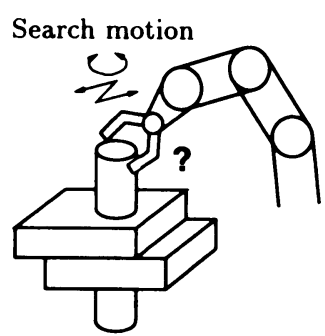

Assembly/Disassembly
Fig. 1 Detection of kinematic constraints 
アルな提示を行うという利用も考えられる。 いったん，拘束状態が検出できれば，拘束に応じた従来の力ゃ 位置の制御法 [10] [11] や動作計画を適用してそれらの作業が行 える。

人間は暗闇のなかでも手探りによる触知覚を用いて器用な作 業ができる．例えば, ドアの開く方向や鍵を回す方向が分から ないと様々な方向に引っ張ったり回したりして動く方向を感じ とる. 拘束を検出するための情報源として視覚も利用できるが, 対象物の形状が分離しにくかったり拘束が隠されていることも 多い. 把持対象物の拘束を調べるには力や変位のセンシングが 直接的である．また，様々な方向に力を加えて対象物の動きを 調べるアクティブセンシング [12] が重要となる．実環境では本 来の拘束の情報だけでなくガ夕や摩擦等の影響も含まれている.

拘束状態を検出する手法として, 分類された拘束状態をそれ ぞれモデル化し，閥値や個々のルールで識別する方法もあるが, 効率的ではなく，センシングの誤差も扱いにくい. 拘束が多自 由度で柔らかさやガ夕が存在するような実環境では, センシン グの誤差を吸収する仕組みが必要である。また，同じ量の変位 が生じた場合でも他の方向との相対的なバランスで拘束の種類 が区別されるため閥値等の設定は煩わしい，そこで本研究では， 拘束状態をニューラルネットワークで表現し汎用的に検出する 手法を提案する．アクティブセンシングで得られる情報は離散 的な方向であるため, ニューラルネットワークの補間能力やパ ターン認識が有効であり, 離散的なデー夕を容易に取り扱える. ニューラルネットワークはブラックボックス的になりがちであ るが, 2 段構造にすることにより学習後の内部状態（リンクの 重み）を陽に扱える新しい手法を提案する。また，サブサンプ ションアーキテクチャのようにセンサ情報の認識結果を直接口 ボットの運動制御に結び付けるのではなく，ロボットの動作計 画に利用しやすいように拘束の種類や姿勢を明示的に出力する 構造をとる. 拘束としては平面 3 自由度の運動拘束を扱い, そ れらを 16 種類に分類して，ロボットが把持した作業対象物が どの種類の拘束でどのような姿勢にあるか, という認識を行う.

\section{2. 探り動作と可動空間}

\section{1 探り動作による拘束の認識の手順}

未知の拘束状態を認識するには，まず，作業対象物をロボッ トに把持させ，動かすときに対象物やロボットが壊れないよう にロボットの手先を力制御している状態で, 様々な方向に微小 な力やモーメントを加えて（微小に動かして）生じる変位と手 先に発生する反力を検出する必要がある.この能動的な動作を 「探り動作」と呼ぶことにする．また，その力を加えた（動か そうとした）方向を「探り方向」と呼ぶ. 得られる変位と力の パターンから探り方向が動く(可動) 方向か動かない（不動） 方向か分かる.あるいは，その探り方向の拘束の剛性が求まる. しかし，実環境ではガタや摩擦の影響があり，それらを本来の 拘束の動きや反力と区別しなければならない.このような探り 動作を様々な方向に絽り返すと離散的な探り方向とその方向に 動くかどうかという情報の組が複数得られる。 それらから対象 物の拘束の種類や姿勢を認識する手順になる（Fig. 2). 本研究 ではこの拘束の認識に 2 段構造のニューラルネットワークを用

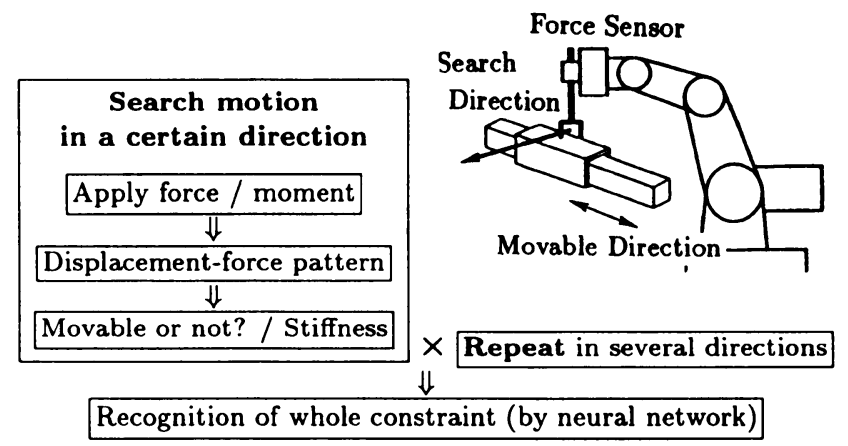

Fig. 2 Procedure of "Search motion" and recognition
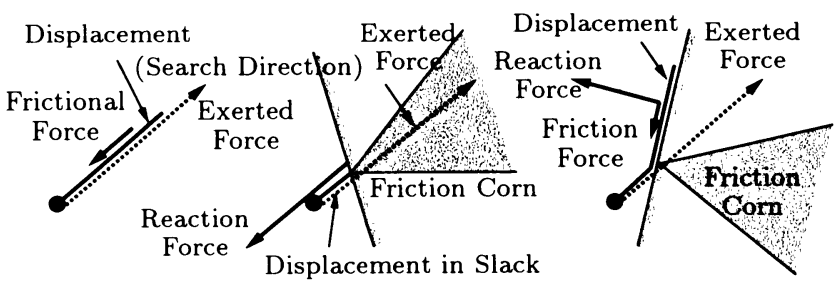

(1) $\begin{aligned} & \text { Movable } \\ & \text { direction }\end{aligned}$

(2) Constrained

(3) Motion along
the constraint

Fig. 3 Motion (displacement/force) in a search direction

いる.

\section{2 探り動作で得られる变位とカの情報}

探り動作を行った時のロボットの手先の動きは基本的には 3 通りに分けられる（Fig. 3).

（1）自由に動く方向に探り動作を行った場合

大きな変位が生じ動きと逆向きに摩擦力を受ける。

（2）拘束されて動かない方向に探り動作を行った場合

最初ガ夕の範囲を動いた後, 拘束に当たり, 加える力が摩

擦円錐の内側にあるため大きな反力が生じて止まる。

（3）可動方向（拘束）に沿って探り方向とずれて動く場合

ガ夕の範囲を動いた後, 加える力の向きが摩擦円錐の外側

にあると, 拘束に沿って移動する. 移動と逆向きに摩擦力, 沿って動く方向に対して垂直に反力を受ける．探り方向の 情報だけでなく沿って動く方向の情報も得られる.

拘束に柔らかさがあるとこれらの中間のような状態が存在する. 連続的に取り扱うには探り方向の拘束の剛性を考えればよい. これは, 探り方向の力と変位のパターンの, ガタや摩擦の影響 を除いた部分から求めることができる. 拘束状態が理想的なら ば, 可動方向は剛性が 0 であり, 不動方向は $\infty$ となる.

\section{3 平面 3 自由度の拘束と可動空間}

本研究では Fig. 4 に示す平面 3 自由度の拘束の識別を考え る. 典型的な拘束を許される微小变位によって 16 種類に分類し た. 並進と回転の運動があり片方向と両方向の拘束がある. 図 の対象物断面が円形のものは回転が自由であり, 正方形は回転 できず, 変形円は片方向のみ回転できることを示す. (7) (10) では三つの図があるが, これらは同じ種類の拘束として扱う. クランクでは並進と回転が一定の割合で連動し，その割合はク ランクを把持する位置に依存する，回転軸上を把持した場合は 回転だけが生じ, 並進のみが生じる滑り対偶は無限遠方を把持 

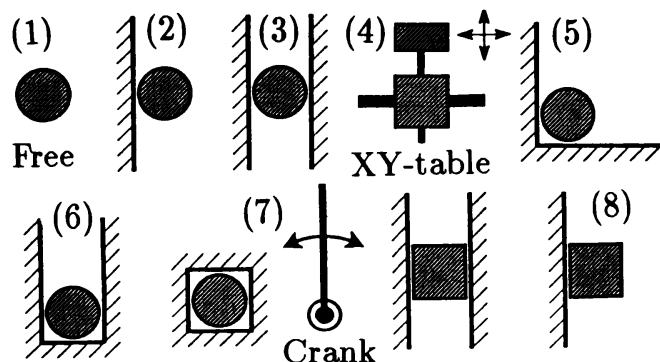

(7)
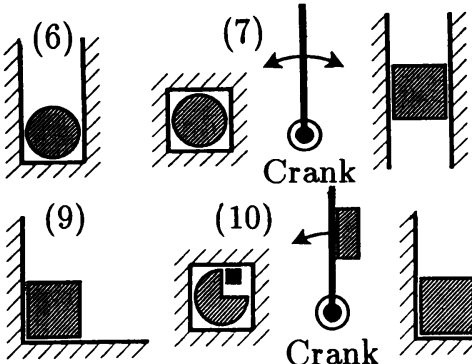

C)
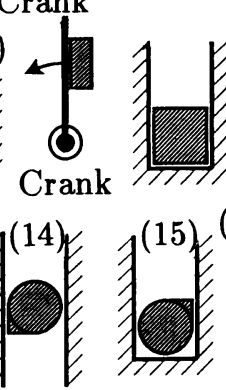

(11)
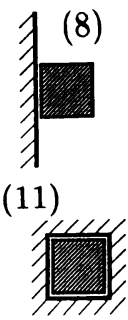

Fixed
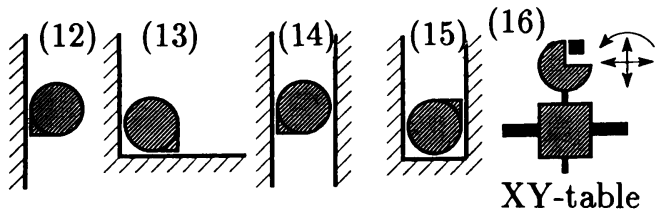

Fig. 4 Classification of typical kinematic constraints in a plane

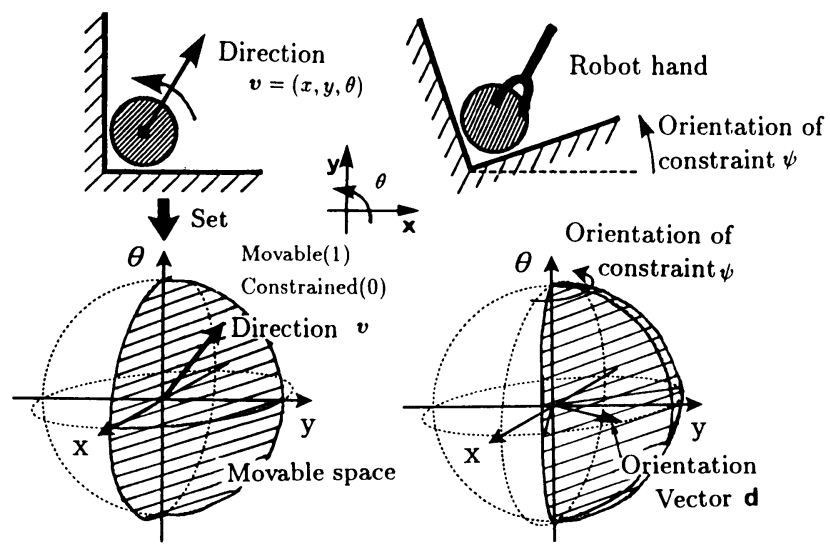

Fig. 5 An example of movable space

した場合とみなせる。これらの可動空間（後述）は方向が異な るだけで形状は同じである。

ロボットが把持する対象物の拘束状態は理想的にはある探り 方向 $\boldsymbol{v}$ に動くか（1）動かないか（0）で表現でき, 動く方向 の集合で「可動空間」を表現できる。平面内運動は並進 2 自由 度, 回転 1 自由度であるので可動空間は三次元 $(x, y, \theta)$ の部 分空間となる. Fig. 5 に可動空間の例として Fig. 4（5）の拘 束の場合を示す．ここで注意しなければならないのは拘束の姿 勢（方向） $\psi$ である. 拘束の姿勢 $\psi$ が变わると可動空間（の 方向）は $\theta$ 軸回りに回転する. 拘束状態を識別するには拘束 の種類と姿勢の検出が必要である．姿勢は拘束のある基準の部 分の角度 $\psi(0 \sim 2 \pi)$ で表せるが， $0(2 \pi)$ で不連続となりニュー ラルネットワークでは扱いづらい。 また，クランクの拘束 $(7)$ （10）では可動空間の形状が直線になるが，その向きは並進と 回転の比によっても変化するため三次元べクトルによる姿勢の 表現が適している．そこで，可動空間の姿勢を表す代表べクト ル $\boldsymbol{d}$ を定めて拘束の姿勢を表す。このベクトル $\boldsymbol{d}$ は，おのお の同じ形状の（同じ種類の拘束の）可動空間に対してある一定

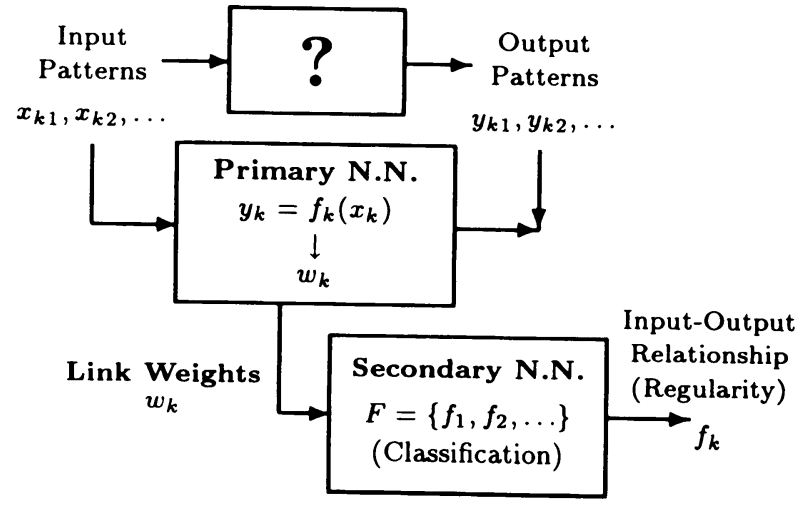

Fig. 6 Structure of two-stage neural network

の方向に設定しておけばよく，姿勢が表現できれば可動空間に 対してどの方向に設定してもよい.

\section{3. 複数の入出力関係を識別する 2 段構造}

$$
\text { ニューラルネットワーク }
$$

拘束の認識に用いるために複数の入出力関係を識別する 2 段 構造のニューラルネットワークを提案する。不明な関係の入力 と出力を観測してどんな種類の関係（関数）なのか，という認 識を行う。通常の階層的ニューラルネットワークの場合, 学習 後のネットワークがどのように入出力関係を実現しているかを 陽に知ることは難しい。しかし，ニューラルネットワークを構 成する各リンクの重み係数が入出力関係の特徵を表していると 考えるのは自然であり, 本研究ではこの点に着目した. Fig. 6 のようにニューラルネットワークを 2 段構造として, 学習を終 えた前段（1段目）のネットワークの重みのパ夕ーンを後段（2 段目）のネットワークの入力として, 前段のネットワークが学 習した複数の入出力関係を識別する, という新しい構造を提案 する．学習後のリンクの重み係数を入出力関係に対応したパ ターンとして利用するわけである。このように, 入出力が複数 のパラメータでもよく，それらが非線形な関係も取り扱える構 造はほかにはあまり見当たらない。

具体的な学習と認識の手順を Fig. 7 に示す. あらかじめ複数 の入出力関係に対してそれぞれ前段ネットワークの学習を行っ て発生したリンクの重みのパターンを得ておき，それらを後段 ネットワークにオフラインで学習させておく. 認識時には，提示 されたある入出力を前段ネットワークが学習し，そのリンクの 重みのパターンから後段ネットワークが入出力関係の種類を識 別する。このような認識を行うには，ある一つの入出力関係に 対して前段ネットワークに決まったパターンのリンクの重みが 発生する必要がある。通常の逆誤差伝播法 [16] では初期値や学 習順序等により様々なリンクの重みが発生してしまう。そこで, 忘却付き構造学習 [17] を利用して次のような前段ネットワーク の学習を行う. 速度修正型の学習則は, $k$ 層 $i$ ユニットに逆伝 播された出力誤差を $\delta_{i}^{k}$ とすると, 学習回数 $t$ 回目の $k-1$ 層 $j$ ユニットから $k$ 層 $i$ ユニットへのリンクの重み $w_{j i(t)}^{k-1, k}$ の修 正量は

$$
\Delta w_{j i(t)}^{k-1, k}=\alpha \Delta w_{j i(t-1)}^{k-1, k}-\epsilon \delta_{i}^{k} o_{j}^{k-1}-\epsilon_{f} \operatorname{sgn}\left(w_{j i(t-1)}^{k-1, k}\right)
$$


となる. 最後の項が忘却の項であり, 残りは通常の逆誤差伝播 学習と同じである. 次の手順で各項の係数 $\alpha, \epsilon, \epsilon_{f}$ の値を変化 させてそれぞれの段階の学習を行う.

（1）小さな乱数をリンクの重みの初期値に設定する.

(2) 逆誤差伝播学習 $\left(\epsilon_{f}=0\right)$ によりリンクの重みを成長させ る. 平均出力 2 乗誤差が小さくなれば収束と判定する.

（3）忘却付き構造学習を用いて圥長なリンクを消去していく. 学習回数 $\Delta t$ おきにリンクの重みの変化の絶対値の和

$$
W=\frac{1}{\Delta t} \sum\left|w_{j i(t)}^{k-1, k}-w_{j i(t-\Delta t)}^{k-1, k}\right|
$$

を計算し，この値が小さくなれば収束と判定する.

(4) 前の層からユニットに慗がるリンクの重みが同じか，ある いは，逆符合で同じ大きさである中間層ユニットが 2 個発 生した場合は，圥長であり，収束を遅らせるだけなので， 一方の重みを小さな乱数に再設定して学習をやり直す.

（5）学習の収束後，最後に中間層ユニットを並べ変える．並べ 変えをしてからリンクの重みのパターンを後段ネットワー クの入力へ渡さないと, 同じ重みのパターンでも中間層工 ニットの並び方の場合の数だけパターンが増えてしまい, 後段ネットワークでの識別の負担になる，並べ変えの指標 としてはユニットの出力に着目し，例えば，ユニットが反 応（1 を出力）する入力の空間の大きさの順に並べる.

なお, 後段ネットワークは逆誤差伝播学習を用いる.

入出力写像の種類を検出する問題に対して, 入力と出力の データを並べて改めて入力パターンとすれば，複数のパターン の特徴量を中間層に出力させる砂時計モデル [15] や時系列デー 夕の認識が可能なリカレントネットワーク [13] [14] も利用でき る。しかし，それらに比べて，本手法は

・与える入出力の組の数が一定でなくてよい.

・順序関係のない入出力パターンでも認識できる.

・認識時にも前段のネットワークの学習が必要である. 前段 は補間や情報圧縮等の前処理的な役割を持っている.

・後段ネットワークは特徵抽出されたリンクの重みのパター ンのデータベースの役割を持つ.

\begin{tabular}{|c|c|c|c|c|}
\hline \multirow{2}{*}{\multicolumn{3}{|c|}{$\frac{\text { Offline (Learning) }}{\text { Input-output patterns are prepared }}$}} & \multirow{3}{*}{\multicolumn{2}{|c|}{$\begin{array}{l}\text { Online(Recognition) } \\
\text { A certain set of input- } \\
\text { output patterns is given. }\end{array}$}} \\
\hline & & & & \\
\hline \multirow{3}{*}{$\mid \begin{array}{c}\text { Input-output } \\
x_{1}, y_{1} \\
\downarrow \\
\text { Learning of } \\
\text { Primary N.N. } \\
\downarrow \\
\text { Link weights } \\
w_{1}\end{array}$} & \multicolumn{2}{|c|}{ for each function. } & & \\
\hline & $\left|\begin{array}{c}x_{2}, y_{2} \\
\downarrow \\
\text { Learn } \\
\downarrow \\
w_{2}\end{array}\right|$ & $\left|\begin{array}{c}x_{3}, y_{3} \\
\downarrow \\
\text { Learn } \\
\downarrow \\
w_{3}\end{array}\right|$ & \multirow[t]{4}{*}{$\Rightarrow$} & $\begin{array}{c}\text { Input-output } x_{\boldsymbol{k}}, \boldsymbol{y}_{\boldsymbol{k}} \\
\downarrow \\
\text { Learning of } \\
\text { Primary N.N. } \\
\downarrow \\
\text { Link weights } w_{\boldsymbol{k}}\end{array}$ \\
\hline & & & & $\Downarrow$ \\
\hline & & Link weigh \\
\hline \multicolumn{3}{|c|}{$\begin{array}{c}\text { Link weights of Primary N.N. } \\
w_{1}, w_{2}, w_{3}, \ldots \quad \text { and } \\
\text { Types of functions } f_{1}, f_{2}, f_{3}, \ldots \\
\downarrow \\
\text { Learning of Secondary N.N. }\end{array}$} & & $\begin{array}{c}\text { Primary N.N. } w_{k} \\
\downarrow \\
\text { Secondary N.N. } \\
\downarrow \\
\text { Type of function } f_{k}\end{array}$ \\
\hline
\end{tabular}

Fig. 7 Learning and recognition of two-stage neural network
といった特徵を持つ。また，入出力関係が線形に限られる場合 には次のような解釈もできる。ある線形な関係 $\boldsymbol{y}_{k i}=A_{k} \boldsymbol{x}_{k i}$ を持つ入出力の組 $\left(\boldsymbol{x}_{k i}, \boldsymbol{y}_{k i}: i=1 \ldots n_{k}\right)$ を前段ネットワーク で学習することは行列 $A_{k}$ の推定にあたり， $A_{k}$ の各要素は前 段のリンクの重み $w_{k}$ に対応する．後段ネットワークではその 行列 $A_{k}$ の各要素を観察して行列の型（種類）を識別すること になる．前段での忘却付き構造学習や中間層の並べ変えは行列 を基本的な性質を保ったまま簡単な形に変形していく操作と考 えられる。

\section{4. 平面 3 自由度の拘束を識別する 2 段構造 ニューラルネットワーク}

平面 3 自由度の拘束 (可動空間) を識別するために入出力関 係を識別する 2 段構造のニューラルネットワークを用いる。そ の構造を Fig. 8 に示す. 前段ネットワークは 16 種類の理想的 な拘束のパターンをおのおの姿勢も変化させてオフラインで学 習する. 入力は探り方向のベクトル $(x, y, \theta)$ であり, 出力はそ の方向が可動方向（1）か不動方向（0）かの識別である. 探り 方向は離散的だが, ニューラルネットワークの能力やノイズを 加えた学習により可動空間が補間されて表現される。なお, 学 習後の中間層の並べ変えはユニットが反応 (1 を出力) する入力 $(x, y, \theta)$ の空間の大きさの順に行う.この学習後の前段ネット ワークのリンクの重みを可動空間が反映したパターンとして利 用する. そこで, 後段ネットワークは前段ネットワークのリン クの重みを入力とし, 拘束の種類と姿势を出力とする関係を才 フラインで学習する．後段のニューラルネットワークは種類と 姿勢に関して二つのネットワークに分けた。一つは入力が前段 ニューラルネットワークのリンクの重みで出力が拘束の種類で ある. 理想的に拘束の種類が識別されたときは出力層のその種 類に対応するユニットのみが 1 , 他は 0 を出力する.もう一つ は拘束の種類の識別結果と前段ネットワークのリンクの重みを 入力して可動空間の姿勢を表す代表ベクトル $\boldsymbol{d}=\left(d_{x}, d_{y}, d_{\theta}\right)$ を出力する.

実際に探り動作を行って，ある拘束状態をオンラインで認識 するときには, 探り動作を行って得られた離散的な可動空間の データをオフラインの場合と同様に前段ネットワークで学習し,

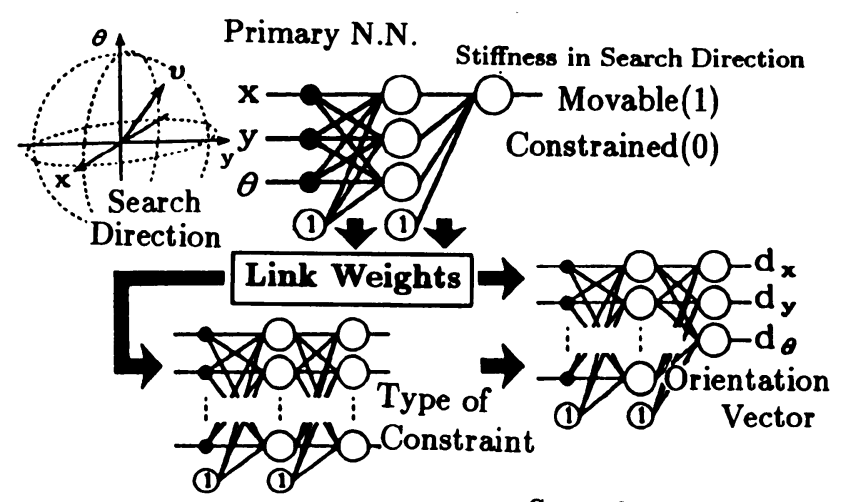

Secondary N.N. 1

Secondary N.N. 2

Fig. 8 Structure of 2-stage N.N. for detecting constraint 


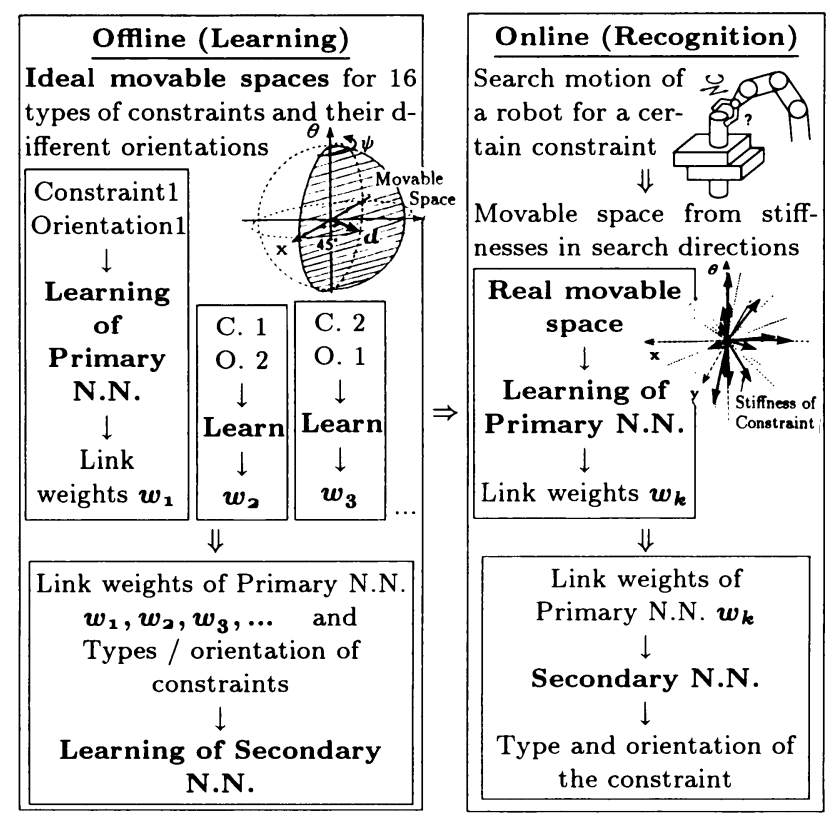

Fig. 9 Learning and recognition of constraints by 2 -stage N.N.

その結果発生した前段のリンクの重みをオフラインで学習済み の後段ネットワークに入力して識別することになる．これらの 平面 3 自由度の拘束を識別する 2 段構造のニューラルネット ワークの学習と認識の手順をまとめると Fig.9 のようになる.

\section{5. 理想的な可動空間に対する認識結果}

平面 3 自由度の理想的な可動空間を用いて 2 段構造のニュー ラルネットワークの学習を行い, 挙動や認識結果を調べた.

5.1 前段ネットワークによる可動空間の学習結果

一例として隅に円柱がある拘束（Fig.4（5））を前段ニュー ラルネットワークで学習した。学習回数は 3,000 30,000 回 （収束速度による）であり，計算時間は 0.7～7.5 [sec]（EPSON PC486RS 使用) であった。発生したニューラルネットワーク のリンクの重みのパターンと中間層や出力層のユニットの出力 を Fig. 10 に示す.リンクの重みは○(+) ○(-)の大きさ で表した. ユニットの出力は, 入力層に入力された方向べクト ル $(x, y, \theta)$ に対して, そのユニットの出力をべクトルの大きさ としてプロットすることで表示した。これはそのユニットが空 間のどの方向に反応（1を出力）しているかを示している。ま た，図の右部に，プロットした中間層と出力層のユニットの出 力の $x y$ 断面図を重ねて表示してある.リンクの重みをみると， 忘却付き構造学習の効果によりて長な重みが消えているが, 初 期値等の影響のため同じ可動空間の学習に対して主に三つのパ ターンのリンクの重みが生じた. 240 通りの異なる初期値に対 して発生回数を調べると, パターン $1: 58 \%$, パターン $2: 14 \%$, パターン $3: 17 \%$ ，その他 (忘却不十分が多い) $: 11 \%$ あった. 同じ可動空間に対して 1 パターンのリンクの重みが発生するの が望ましいが，数種類ならば後段ネットワークでリンクの重み から可動空間を十分識別できる.ユニットの出力に注目すると, 明らかであるが, 出力層のユニットの出力は学習させた理想的 な可動空間の形とほほ等しい. 中間層のユニットは空間のある

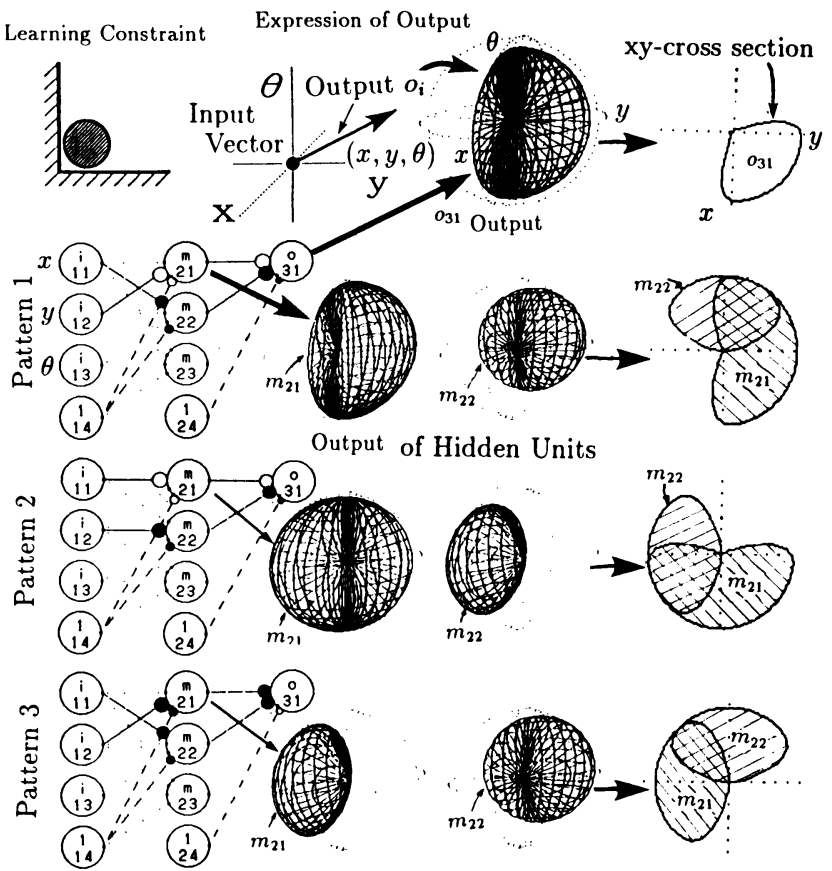

Generated Primary N.N.

(Link Weight: $\mathrm{O}+10$ : -10 )

Fig. 10 Generated link weights and activations of Primary N.N.

まとまった方向に反応しており，概してそれらの和・差・補・ 交わり集合等から出力層のユニットの出力（可動空間）が構成 されている様子がみられる．可動空間の種類が変わると発生す るリンクの重みのパターンや中間層ユニットが反応する空間の 大きさはそれぞれ異なったが，同様の性質が見られた。

\section{2 可動空間の姿勢とリンクの重みの関係}

発生する前段ネットワークのリンクの重みのパターンに可動 空間の姿勢に応じた，ある程度の規則性がないと後段ネット ワークでの認識の負担が大きくなる．そこで可動空間の姿勢 $\psi$ の変化に応じてリンクの重みがどう変わるかを調べた. Fig. 4 （5）の拘束を例として姿勢 $\psi$ を 0～ $360[\mathrm{deg}] ， 15$ [deg] おきに 変えてそれぞれ学習後（各 10 回ずつ）生じたリンクの重みの 一部を Fig. 11 に示す. ある一つの姿勢 $\psi$ に対しても 1 数種 類のリンクの重みが生じている．かなりばらつきがあるが, 姿 勢に対してリンクの重みが三角関数的に変化している部分がみ られる。このとき各ユニットの出力を調べると可動空間の姿勢 が変わっても反応している空間（出力）の形は変わらないが, 方向は姿勢に連動して変化する様子が見られた。これらは前段 ネットワークのリンクの重みを入力として後段ネットワークが 可動空間を識別したり姿勢べクトルを出力したりするのに良い 性質である。

\section{3 後段ネットワークの学習と可動空間の識別結果}

16 種類の拘束（可動空間）に対し姿勢を 15 [deg] おきに変 えてそれぞれ前段ネットワークの学習を行い, 4,960 個のリン クの重みのパターンを得た。それらと拘束の種類あるいは姿勢 （代表ベクトル）の関係を後段ネットワークに学習させた. 学 習は 30 万回行い, 計算時間は, 例之ば, 拘束の種類の学習で 中間層 20 個のとき 290 [sec]（SUN SparcStation20 使用）で 
あった．Fig. 12 に，中間層のユニット数を変えたときの拘束 の種類と姿勢の学習結果 (全体) と, 二つの後段ネットワーク
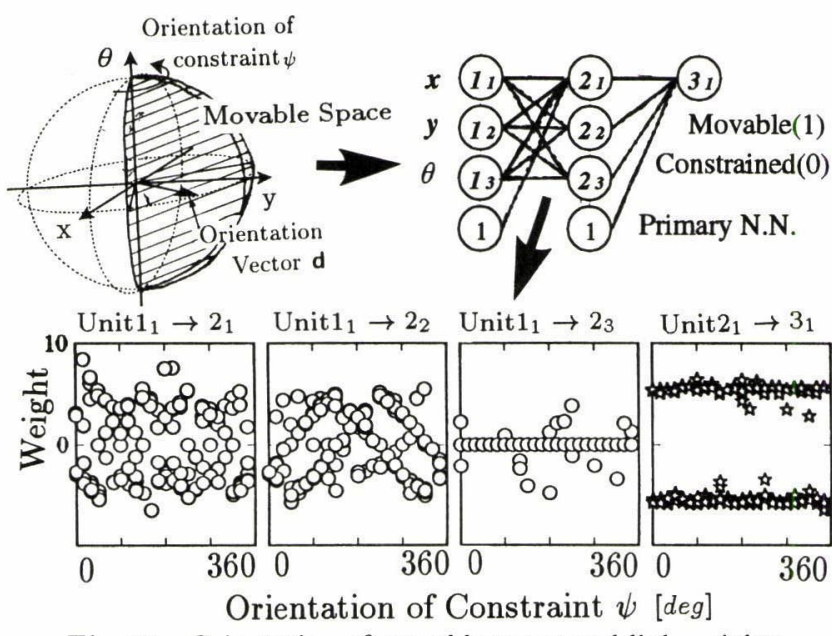

Fig. 11 Orientation of movable space and link weights

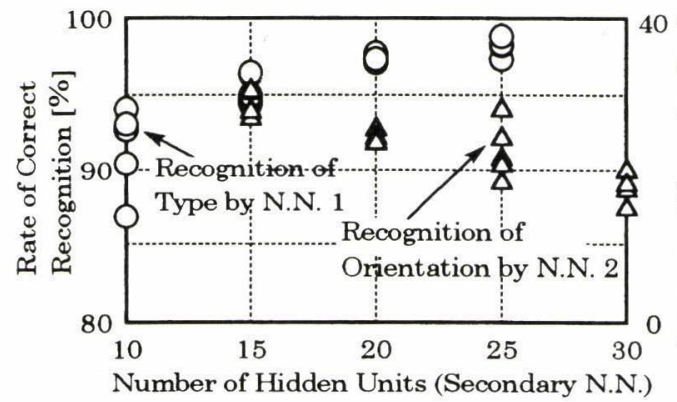

\begin{tabular}{|c|}
\hline$\sum_{0}^{0} \cdot \frac{0}{5}$ \\
\hline
\end{tabular}

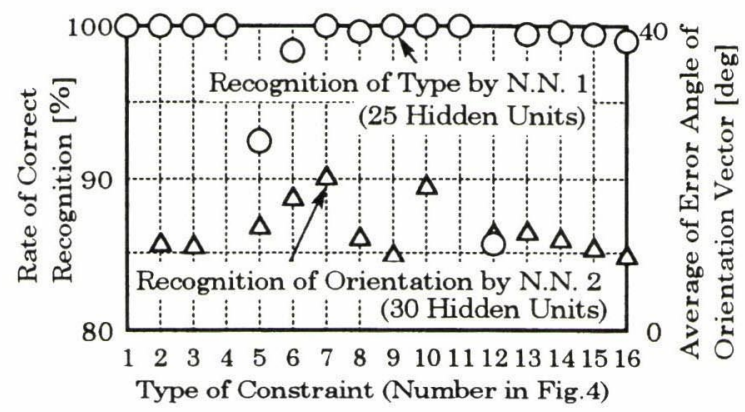

Fig. 12 Recognition result of the type/orientation of constraint

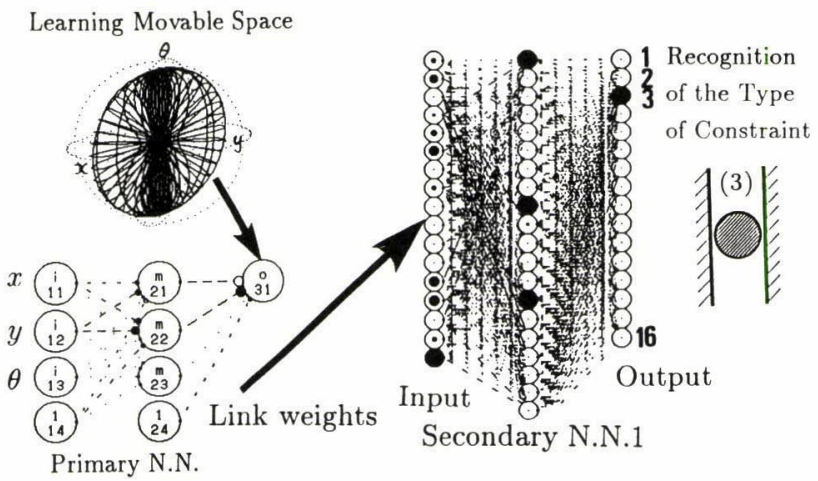

Fig. 13 An recognition example of the type of constraint
の中間層のユニット数がそれぞれ 25,30 個の場合の学習結果 を 16 種類の拘束の種類ごとに示す。学習に用いたリンクの重 みのデータを後段ネットワークに入力したときの拘束の種類の 識別率と姿勢ベクトルの角度誤差（ベクトルのなす角）の平均 を示している. 少々ばらつきはあるが, リンクの重みから 16 種 類の拘束が識別できている，姿勢べクトルの精度はおおよその 拘束の向きが分かる程度（10－30[deg]）である．また，前段 ネットワークに可動空間を学習させ, リンクの重みのパターン を学習済みの後段ネットワークに入力して拘束の種類を識別し た例を Fig. 13 に示す. 後段ネットワークの各ユニットの出力 はの大きさで表示した。後段ネットワークの出力層のユニッ 卜は16 種類の拘束 (の番号) にそれぞれ一つずつ対応してい る. 前段ネットワークに与えた拘束の種類の出力層ユニットが 反応している。これらから 2 段構造のニューラルネットワーク により前段のリンクの重みのパターンを利用して拘束の種類や 姿勢を検出できることが分かった。

\section{6. 実環境での探り動作による拘束の認識}

実際のロボットで把持した対象物に探り動作を行って，その 時の変位と力のパターンから得られた可動空間の認識を行った.

\section{1 実験システムと探り動作の制御}

探り動作の実験のために構成したシステムを Fig. 14 に示す. (株) 三菱電機製の 5 自由度多関節型ロボットMOVE MASTER EX を使用した。手先の力は手首に取り付けた 6 軸力覚 センサで測定し, 変位は各関節角から運動学により求めている. 探り動作中に対象物を壊さないように柔らかく動かすためアー ムにはコンプライアンス制御を用いた。速度（位置）制御型の ロボットに適用しやすい, 力と位置をフィードバックし各関節 の速度目標値を求めるアルゴリズム $[18]$ を使った。作業座標系 の仮想インピーダンスを剛性行列 $K_{d}$, 隇衰係数行列 $D_{d}$, 慣 性行列 $M_{d}$ とし, 位置 $\boldsymbol{x}$, 目標值 $\boldsymbol{x}_{\boldsymbol{d}}$, 外力 $\boldsymbol{F}$, 目標值 $\boldsymbol{F}_{\boldsymbol{d}}$ と すると

$$
M_{d} \ddot{\boldsymbol{x}}+D_{d} \dot{\boldsymbol{x}}+K_{d}\left(\boldsymbol{x}-\boldsymbol{x}_{\boldsymbol{d}}\right)=\boldsymbol{F}-\boldsymbol{F}_{\boldsymbol{d}}
$$

に従うように手先 $x$ を動かす．探り動作中 $K_{d}, D_{d}, M_{d}$ は一定 にした。ある方向に探り動作を行うには力の目標値 $\boldsymbol{F}_{\boldsymbol{d}}$ を探 り方向に準静的に増やす。これは仮想的なばねの平衡点 $\boldsymbol{x}_{\boldsymbol{d}}$ を 探り方向にずらすのに等しい. 平面内 $(x, y, \theta)$ の探り動作で は力とモーメント $\left(F_{x}, F_{y}, M_{z}\right)$ を加える. 実験では力 $0.5[\mathrm{~N}]$,

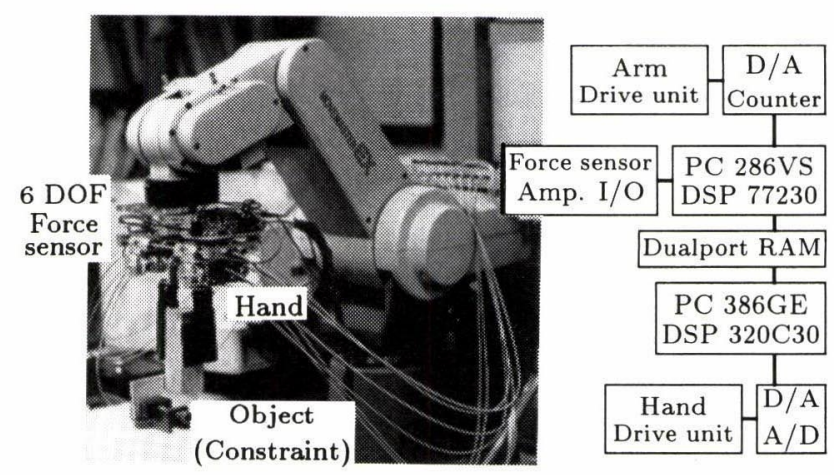

Fig. 14 Robot system for search motion 


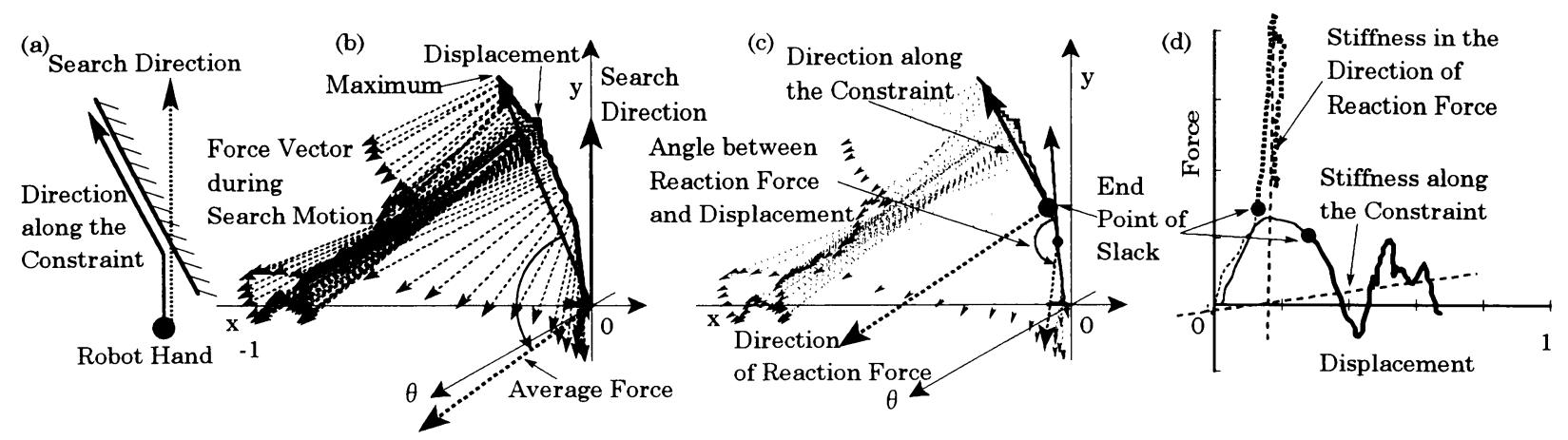

Fig. 15 Displacement-force pattern obtained by a search motion and its analysis

モーメント $0.03[\mathrm{Nm}]$ （探る範囲 $10[\mathrm{~mm}], 15[\mathrm{deg}] ）$ を 1 [sec] 程加えた.

6.2 探り動作の变位とカのパターンから得られる可動空間 ある一つの方向に探り動作を行って得られた変位と力のパ ターンの例とその処理を Fig. 15 に示す.これは可動方向に探 り方向とずれて動く場合である（(a)).（b）はその探り動作中 の手先の変位（軌跡）と受けた力のベクトルを並進と回転の三 次元空間 $(x, y, \theta)$ で表示したものである.このような変位と力 のパターンから次のようにして可動空間を得る. 基本的には, 動く場合, 動かない場合, 可動方向に沿って動く場合を区別し, ガタの影響を除いてその探り方向の剛性を求める.

（1）前処理としてカのデータにローパスフィルタをかける. 変 位とカのパターンは，それぞれ，完全に自由なときの変位 と完全に拘束したときの反力の最大值で正規化する.

（2）変位が小さいときは動かない場合とみなす．探り動作中の 平均した力ベクトルの方向と最大の変位の方向が逆向きの ときは動く場合とする.（b）のようにそれらが垂直に近い ときは可動方向に沿って動く場合とみなす。

（3）ガ夕の範囲の動きを除くため, 動く場合は変位が生じ始 める点を, 動かない場合は反力が生じ始める点を検出し, その後の変位と力のパターンを直線近似して剛性 $K$ を求 める.

（4）沿って動く場合は, (c) のように移動方向と反力の角度が 垂直に近くなる点を検出する。これは, ガ夕の動きの後,

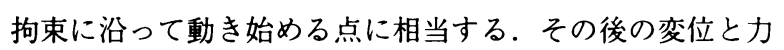
から, 拘束に沿う方向と反力を受ける方向 $((\mathrm{c}))$ の成分 をグラフ化すると（d）のようになり，それぞれの方向に ついて変位と力の関係を直線近似して剛性 $K$ を求める.

様々な方向に探り動作を行い，このような処理を繰り返すこと で離散的な可動空間が得られる. 理想的な可動空間は $1 / 0$ で表 したが,ここでは探り方向の拘束の剛性 $K$ に対し, 探り方向に

$$
K^{\prime}=1-\frac{2}{\pi} \tan ^{-1} K \quad\left(0 \leq K^{\prime} \leq 1\right)
$$

の大きさのベクトルで可動空間を表す，隅に円柱がある拘束の 例について 18 の探り方向から得た可動空間を Fig. 16 示す.

6.3 探り動作で得られる可動空間の認識のためのニューラ ルネットワークの改良

実際の探り動作で得られる可動空間はセンシングの誤差を多

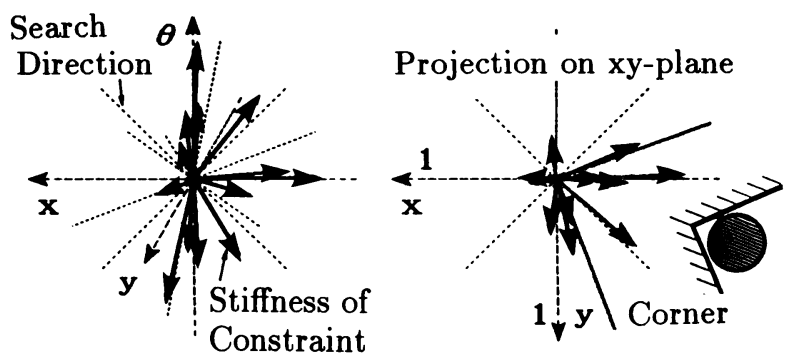

Fig. 16 Movable space of sampled stiffnesses

く含んでいる，それらに十分対応できるよう 2 段構造のニュー ラルネットワークの構造と学習を次のように改良した。

(1) 探り方向の拘束の剛性で表された可動空間は大きさやオフ セットのばらつきが大きい.このばらつきによらず一定の リンクの重みが発生しやすいように, 前段ネットワークを 出力層に線形ユニットを持つ 4 層構造にする (Fig. 17). 3 層目のユニットが理想的な $1 / 0$ の可動空間を出力するよ うな学習を行って, 線形ユニットのリンクの重みに大きさ やオフセットを吸収させるようにすると， 3 層目までのリ ンクの重みは可動空間のばらつきの影響を受けにくい，具 体的には次のように学習を変更する。

(a) 3 層目までのリンクの重みの成長が速く, 出力層は遅 いように学習係数を設定して誤差逆伝播学習を行う.

（b）出力層のリンクの重みをいったん小さくし，中間層は 出力が $1 / 0$ に近づくような学習 [17] を併せて行う. 出 力層を除いて忘却付き学習を行って圥長な重みをな くす。

(c) 3 層目までのリンクの重みを後段ネットワークの入力 とする.ユニット毎に, 前層からそのユニットに䋜が るリンクの重みを並べて一つのベクトルにし，その大 きさと大きさ 1 に正規化したべクトルの成分を渡した。 大きさとオフセットを変えた可動空間を 4 層の前段ネット ワークに学習させた結果を Fig. 17 に示す. 表示したユニッ トの出力をみると, 3 層目のユニットに理想的な $1 / 0$ の可 動空間が発生しているのが分かる.

（2）面に角柱が接している拘束の場合（Fig.4（8）（9）: 回転が 両方向とも拘束, (12)（13）: 片方向のみ拘束), 回転自由 度無しとして理想的な可動空間を考えたが，実際の対象物 
の大きさを考慮すると Fig. 18 のように面から離れる方向 に探り動作を行ったとき回転が少し許される，許される微 小変位の関係は $\Delta h \simeq s \Delta \theta$ であり, 可動空間が $x y$ 平面 上に限られずに回転 $\theta$ の方向に少し広がりを持つ. 実際に 探り動作を行った場合にも図のように可動空間の広がりが 見られた。このような場合の認識を高めるため, 大きさに よる回転の微小変位を考虑した学習デー夕（可動空間）も 加える。

（3）拘束の姿勢の検出精度を上げるため, 拘束の姿勢を表す代 表ベクトルを可動空間の中心付近に統一的に設定し, 後段 ネットワークの学習の負担を減らす。このように設定し, 16 種類の拘束の姿勢を $15[\mathrm{deg}]$ おきに変えて学習させた 前段ネットワークのリンクの重みのデータ 8,080 個（対象 物の大きさを考慮したデー夕も含む）を用いて後段ネット ワークの学習を行った。 その結果, 姿勢ベクトルの誤差の 標準偏差は中間層が 25 個のとき 11.8 [deg] とかなり改善

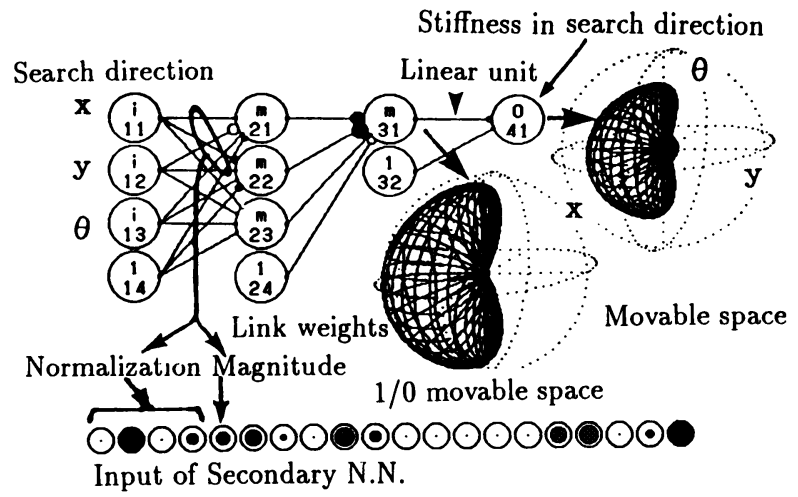

Fig. 17 Primary network with 4 layers for real movable space

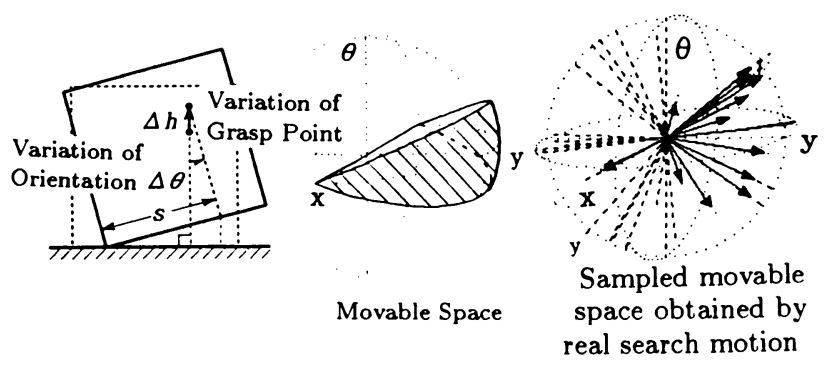

Fig. 18 Movable space when the object size is finite
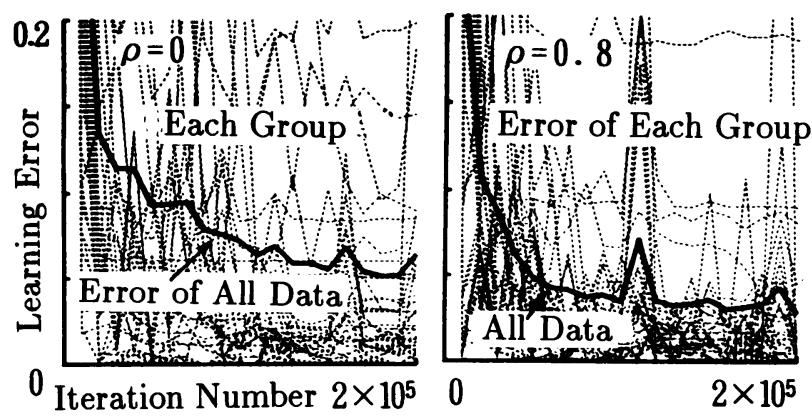

Fig. 19 Convergence by group learning
された。

（4）拘束の種類による後段ネットワークの学習結果のばらつき を少なくするためグループ学習を行う．拘束の種類や姿愂 を基準に学習データをグループ分けし，一定の学習回数お きに学習が進んでいないグループほど提示の割合を大きく する.グループ $i(1, \ldots, n)$ の提示率は, グループごとの 学習誤差 $E_{i}$, 平均 $\hat{E}$ と最小値 $E_{\min }$ から

$$
P_{i}=\frac{1}{n}\left(1+\rho \frac{E_{i}-\hat{E}}{\hat{E}-E_{\min }}\right) \quad\left(\sum_{i=1}^{n} P_{i}=1\right)
$$

$\rho(0 \leq \rho \leq 1)$ は提示率への誤差の寄与である. Fig. 19 に 教師データの提示率 $\rho$ を変えたときの学習を示す.グルー プ学習を行う $(\rho=0.8)$ とばらつきが少なく収束も速い.

6.4 探り動作で得られた可動空間による拘束の識別結果

探り動作で得られた離散的な可動空間から，改良した 2 段構 造のニューラルネットワークを用いて拘束の種類の識別を試み た. Fig. 20 のように拘束の柔らかさや大きさの影響を含む実 際の可動空間の識別ができることが分かった。しかし，Fig. 21 のように理想的な可動空間の形に比べて誤差が大きく識別を誤

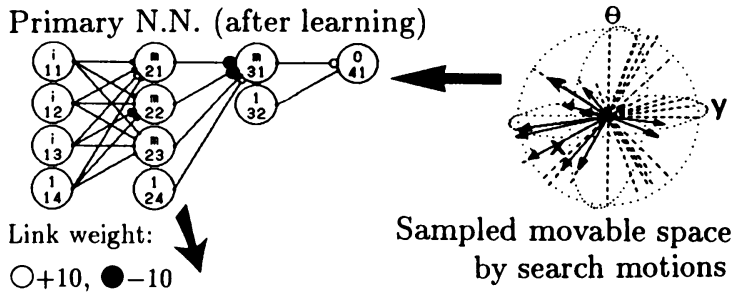

Secondary N.N.1 (Input layer) Pattern of

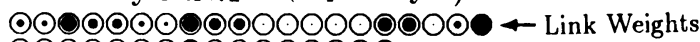
$\bigcirc_{12}$

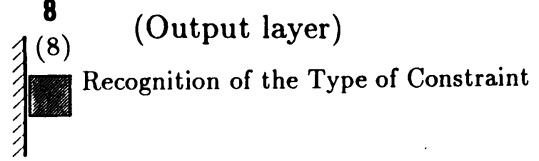

Fig. 20 An example of the recognition from a sampled movable space

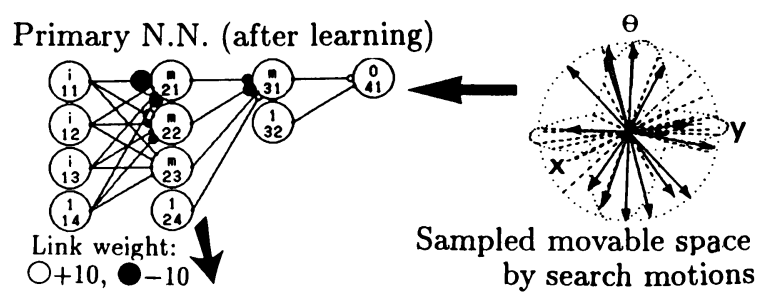

Secondary N.N.1 (Input layer)

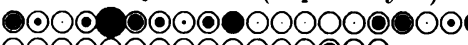
$000000000000000 \bigcirc$

123

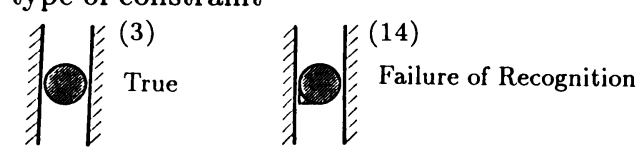

Fig. 21 An example of the recognition from a sampled movable space 
る例も見られた．実際の拘束の柔らかさやガ夕等の程度により， 得られる可動空間は形状のばらつきが大きく, ある程度の変動 には対応できるが，それにも限界がある。

\section{7. ま と}

本研究では, ロボットに探り動作を行わせて力と変位の情報 から未知の運動拘束を検出する方法を示した． 2 段構造のニュー ラルネットワークを用いる手法により 16 種類に分類した平面 3 自由度の拘束の可動空間を学習させて, 拘束の種類と姿勢を識 別させることができた。離散的で誤差のある探り動作のセンシ ング情報を 2 段構造のニューラルネットワークを用いて処理し, その後の動作計画に利用しやすいよう, 識別結果として拘束の 種類と姿勢を明示的に出力しているという点で，モデル化が複 雑な下位のセンサ情報処理とモデルベーストなロボットの動作 計画を結び付ける手法として有効である。しかしながら，実環 境のセンシング誤差が大きい場合には䛊認識も見られた。主と して, 可動空間をリンクの重みで表現させる前段ネットワーク の学習の問題であり, 探り動作で得られた離散的な可動空間か ら大きな構造だけを抽出するような, 例えば, 有効な中間層工 ニットの数をできるだけ少なくしていくような, 学習の工夫が 必要である.また, ニューラルネットワークに入力する前のセ ンサ情報処理である, 変位と力のパターンから離散的な可動空 間を得るときに, ルールや閾值による判断がいくつか入ってい るため, センシング䛊差が大きいと影響を受けて判断ミスを起 しやすく, 改良が求められる.さらに, 三次元 6 自由度の拘束 の認識や効率的な探り動作の戦略も今後の課題として挙げられ る. 対象物の運動や空間の認識は知能ロボットの根本的な問題 であり, 知能化のためには, 運動や位置関係を数值や数式で細 かく記述するような認識手法ばかりでなく，それらの大まかな 関係をセンシングしたり認識したりする手法も必要と考えら れる。

\section{参 考 文 献}

１１］平井 他：“凸多面鍾理論を用いたマニピュレーションの運動学とそ の把握および組立作業への応用”，計測自動制御学会論文集，vol.24， no.12, pp.1284-1291, 1988.
[2] 平井他：“組立作業における位置・力信号の解釈による識別とモデ ルをもとにした識別手続きの自動生成”, 計測自動制御学会論文集, vol. 26 , no. 2 , pp. $225-232,1990$.

[3] Ohwovoriole and Roth: "An Extension of Screw Theory," Trans. ASME J. of Mechanical Design, vol.103, pp.725-735, 1981.

[4] 比留川, 松井, 高瀬： “多面体間の接触による拘束条件を幾何モデル から導出する一般的なアルゴリズム”，日本ロボット学会誌，vol.9, no.4, pp.415-426, 1991.

[5] D.E. Whitney: "Quasi-Static Assembly of Compliantly Supported Rigid Parts," Trans. ASME, J. of Dynamic Systems, Measurement and Control, vol.104, pp.65-77, 1982.

[6] T. Lozano-Perez et al.: "Automatic Synthesis of Fine-Motion Strategies for Robots," Int. J. Robotics Research, vol.3, no.1, pp.3-24, 1984

[7] 内山：“接触状態のシミュレーション”, 日本ロボット学会誌, vol.11, no.2, pp.201-205, 1993.

[8] H. Asada: "Teaching and Learning of Compliance Using Neural- Nets: Representation and Generation of Nonlinear Compliance," Proc. IEEE Int. Conf. on Robotics and Automation, pp.1237-1244, 1990.

[9] M. Vukobratović and D. Katić: "Connectionist Learning Control Algorithms for Contact Tasks in Industrial Robotics," 24th ISIR, pp.643-650, 1993.

[10] M.T. Mason: "Compliance and Force Control for Computer Controlled Manipulators," IEEE Trans. on Systems, Man, and Cybernetics, vol.SMC-11, no.6, pp.418-432, 1981.

[11] N. Hogan: "Impedance Control: An Approach to Manipulation: Part I, II, III," Trans. ASME J. of Dynamic Systems, Measurement and Control, pp.1-24, 1985.

[12] 石川：“アクティブセンシングとロボットハンド”, 日本ロボット学会 誌, vol.11, no.7, pp.938-942, 1993.

[13] M.I. Jordan: "Attracter Dynamics and Paralelism in a Connectionist Sequential Machine," Proc. of the 8th Annual Conf of the Cognitive Science Society, pp.531-546, 1986.

[14] J.L. Elman: "Finding Structure in Time," Cognitive Science, vol.14, pp.179-211, 1990.

[15] 入江，川人：“多層パーセプトロンによる内部表現の獲得”，電子情 報通信学会論文誌, vol.J73-D-II, no.8, pp.1173-1178, 1990.

[16] D.E. Rumelhart et al.: "Learning Internal Reprensentations by Error Propagation, Parallel Distributed Processing: Explorations in the Microstructures of Cognition: Vol.I," Cambridge, MA, MIT Press, pp.318-362, 1986.

[17] 石川：“忘却を用いたコネクショニストモデルの構造学習アルゴリズ 厶", 人工知能学会誌, vol.5, no.5, pp.595-603, 1990.

[18] 平林 他： “多自由度ロボットの仮想コンプライアンス制御”, 計測自 動制御学会論文集, vol.22, no.3, pp.343-350, 1986.

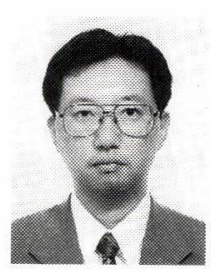

関 啓明 (Hiroaki Seki)

1966 年 9 月 13 日生. 1986 年東京大学工学部精密 機械工学科卒業. 1994 年東京大学大学院博士課程 満期退学後, 東京大学工学部助手. 1997 年金沢大 学工学部助手、ロボットのセンシング等の研究に 従事. 博士 (工学)。精密工学会, 日本機械学会会 員.

(日本ロボット学会正会員)

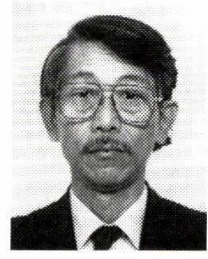

高野政晴（Masaharu Takano）

1936 年 11 月 25 日生. 1960 年東京大学卒業. 1968 年東大助教授. 1980 年同工学部精密機械工学科 教授. 1997 年関西大学工学部教授。専門分野は 機構学, 振動学, ロボット工学. 機械運動の高速 化，ロボットの機構・運動制御，福祉ロボット等 を研究. 工学博士. 精密工学会, 日本機械学会会 員.

(日本ロボット学会正会員)

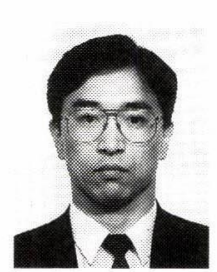

佐々木健（Ken Sasaki）

1957 年 1 月 15 日生. 1980 年東京大学工学部精 密機械工学科卒業. 1987 年東京大学より工学博 士の学位取得. 1982 年から 1985 年まで日本電気 （株）に在職. 現在, 東京大学工学部助教授。触覚 センサ, 多指ハンドのマニピュレーション, 移動ロ ボット用超音波センサに興味がある。精密工学会会 員.

(日本ロボット学会正会員) 